\title{
Nye læringsmål kræver nye eksamensformer
}

Signe Skov, specialkonsulent, RUC.

\begin{abstract}
Artiklen præsenterer og diskuterer et kvalitetsudviklingsprojekt på RUC som har haft til formål at udvikle eksamensformer så de bliver mere laringsunderstøttende og mere valide og relevante i forhold til de læringsmål uddannelserne opstiller. Artiklen præsenterer eksempler på eksamensformer som udprover fx samarbejdskompetence og eksamensformer som, gennem problembasering, autenticitet og bevidste placering $i$ det samlede lxringsforløb, understøtter de studerendes læreprocesser.
\end{abstract}

\section{Indledning og problemfelt}

I denne artikel vil jeg præsentere og diskutere resultaterne af et kvalitetsudviklingsprojekt på RUC som har haft fokus på udvikling af eksamensformer. Målet har været at gøre de traditionelle kursuseksamener mere læringsunderstøttende og mere valide, det vil sige bedre egnede til at udprøve og dermed "aligne" de mere komplekse læringsmål mange af uddannelserne formulerer i disse år blandt andet på baggrund af Dansk kvalifikationsramme for de videregående uddannelser (Ministeriet for Forskning, Innovation og Videregående Uddannelser, 2008). Hvor eksamener - generelt og på RUC - hidtil har villet dokumentere kompetencer inden for akademia og har taget form primært som skriftlige opgaver og overhøring, skal eksamener i dag også dokumentere arbejdsmarkedsrelevante kompetencer som fx samarbejdskompetence, læringskompetence og færdigheder der knytter sig til beskæftigelse inden for de pågældende fagomåder (Ministeriet for Forskning, Innovation og Videregående Uddannelser, 2008). Disse kompetencer har de nævnte eksamensformer vanskeligt ved at udprøve, og et af målene i udviklingsprojektet har været at supplere, opdatere og udvikle nogle mere autentiske eksamensformer.

Et andet mål med eksamensudviklingsprojektet har været at understøtte de studerendes læring. De studerende orienterer sig i høj grad efter hvad de bliver bedømt på, den såkaldte backwash-effekt (se fx Biggs, 2007, s. 169). Og eksamen har som redskab til at regulere de studerendes adfærd således en enorm indflydelse på de studerendes læringsstrategier (Boud, 1999, s. 413). Målet i udviklingsprojektet har været at udvikle og bruge eksamensformer som fremmer de studerendes dybdestrategier i deres tilgang til læringsopgaver. Det vil sige understøtter at de går til stoffet med henblik på at forstå, se sammenhænge og strukturer, relatere og perspektivere i modsætning til overfladestrategier hvor de studerende går til opgaven med henblik at leve op til nogle ydre, lærerens, krav og ikke anspores til at se sammenhænge, me- 
ning og relationer (se fx Ramsden, 1999, s. 63-64).

Projekteksamen, som er RUC's varemærke, er ikke indgået direkte i udviklingsprojektet fordi den allerede i vid udstrækning rummer mange læringsfremmende elementer, som fx problemorientering, samarbejde og selvansvar samt understøtter udviklingen af de mere komplekse (sociale og affektive) kompetencer der efterspørges i dag (jf. senere i artiklen). Men projekteksamen er indgået som bagtæppe for diskussionerne af de traditionelle kursuseksamener. En del af øvelsen har nemlig samlet set været at få skabt en klar sammenhængende progression i opbygningen af de studerendes faglige, metodiske, sociale og affektive kompetencer udtrykt i klare læringsmål og bedømmelseskriterier samt relevante eksamensformer. Disse ting har traditionelt været mere lokalt og løst fastsat på RUC.

\section{Baggrund og forløb}

Særligt i Storbritannien og Australien er der i disse år fokus på at udvikle eksamen og eksamensformer i retning af at bedømme mere for læring og ikke kun af læring1. Det implicerer blandt andet at man arbejder mod:

- Selvansvarlighed - de studerende skal i højere grad inddrages i valg af eksamensform, i fastsættelse af bedømmelseskriterier, i egen- og peer-bedømmelsen.

- Feedback - de studerende skal i højere grad give, modtage og bruge (peer-)feedback så de kan overvåge og strukturere deres egen læring.

- Autenticitet - de studerende skal i højere grad udprøves i anvendelse af viden i praktiske situationer og i forhold til arbejdsmarkedsrelevante problemstillinger.

Også i udviklingsprojektet på RUC har selvansvarlighed, brug af feedback og autenticitet været nogle af nøgleordene som led i at tænke eksamen som en del af det samlede læringsforløb og livslang læring. Og måden at få sat fokus på disse ting har i projektet været at få dem indarbejdet og beskrevet i studieordningerne. Studieordningen er et meget centralt styringsinstrument for underviseres, studerendes og censorers beslutninger om hvad der skal prioriteres i undervisning, eksamen og bedømmelse.

Konkret har projektet været tilrettelagt sådan at jeg har sparret med hver enkelt studieleder og andre relevante fagpersoner på uddannelserne i forbindelse med deres arbejde med at udforme nye studieordninger. Og det har ført til udvikling og brug af nye eksamensformer samt mere præcise beskrivelser af eksamensformerne i studieordningerne.

\footnotetext{
${ }^{1}$ Se fx Assessment Standards Knowledge exchange (http://www.brookes.ac.uk/aske/) og Assessment 2020: Seven propositions for assessment reform in higher education (Boud, 2010).
} 


\section{Krav til eksamen}

Eksamen er ikke en uddannelsesmæssig aktivitet som det er nemt uden videre at ændre på. Et centralt element ved eksamen er at kontrollere om og dokumentere, at færdige kandidater har de kompetencer som er tilstrækkelige og relevante i forhold til at opnå bestemte titler/grader og bestride bestemte jobfunktioner. Det indebærer blandt andet at reliabilitet og validitet er i orden, det vil sige at bedømmelsen af en eksamenspræstation ikke er afhængig af hvem der bedømmer den, og at det der bedømmes, rent faktisk også er det man ønsker at bedømme.

Desuden skal eksamenerne leve op til lovgivningen på området. Det er dog sjældent lovgivningen der spænder ben for udvikling af eksamen fordi bekendtgørelserne kun fastsætter nogle overordnede rammer i forhold til tilrettelæggelse af eksamen. En undtagelse herfra er dog afskaffelsen af gruppeeksamen med Eksamensbekendtgørelsen i 2006 og siden genindførelsen af gruppeeksamen med Eksamensbekendtgørelsen fra 2012. Bestemmelser om antallet af eksaminander ved en eksamen er en meget konkret styring, ikke bare af uddannelsernes eksamenstilrettelæggelse, men også i tilrettelæggelsen af undervisnings- og arbejdsformer. De studerende orienterer sig som tidligere nævnt i vid udstrækning efter hvad de bliver bedømt på. Og skal eksamen afvikles som en individuel præstation, er det også den form for præstationer de studerende vil "øve" sig på frem mod eksamen.

Eksamen er også forbundet med mange vaner og traditioner, og der kan være en vis inerti i forhold til at få ændret på mangeårig praksis (Lauvås, 2004, s. 14). Hvis eksamensformen ikke er valgt ud fra nogle bevidste kriterier, men blot er en gentagelse af sædvanlig praksis, er man heller ikke sporet ind på at der af hensyn til læring og validitet kunne være grund til at vælge nogle andre eksamensformer. Desuden kræver pædagogisk udvikling tid. Det tager tid at udvikle nye eksamensformater, kolleger skal inddrages og andre undervisningsformer skal tages i brug. Også fra de studerendes side kan man opleve forbehold over for ændringer af eksamen. Studerende kan have brug for at holde fast i velkendte formater i eksamenssituationer som i sig selv er situationer der har elementer af usikkerhed og utryghed over sig.

Desuden skal eksamen tage hensyn til de studerendes retssikkerhed og undgå vilkårlighed i bedømmelsen. Og endelig spiller også økonomiske og praktiske hensyn ind i valget af eksamensform.

Samlet set er disse forhold medvirkende til at eksamensformer kan være svære at ændre på. Ikke desto mindre er det en god ide at undersøge mulighederne for det fordi eksamen som nævnt er et væsentligt læringsredskab, og at man ved at vælge nogen bestemte eksamensformer kan understøtte mere effektiv læring. Og fordi nye og mere komplekse læringsmål er mål som de traditionelle eksamener kan have svært ved at måle, og at validiteten ved disse eksamener dermed ikke er ret høj. 


\section{Mod mere læringsunderstøttende og valide eksamensformer}

Helt grundlæggende har vi i udviklingsprojektet drøftet mulighederne for at tænke eksamener tidligere ind i kursusforløb og ikke altid placere dem til sidst. Af flere grunde. Dels afføder eksamener en række faglige produkter udformet af de studerende. Og i forhold til vidensdeling, peer-læring og autenticitet ville det være oplagt i samme semester, men efter eksamen, at arrangere faglige arrangementer hvor de studerende præsenterer egne og forholder sig til medstuderendes eksamensprodukter. Dels er eksamen en faglig aktivitet der, ligesom undervisning og vejledning, løbende bør evalueres/bliver evalueret, og det er mere oplagt for studerende og underviser at evaluere eksamen umiddelbart efter dens afvikling frem for at vente til det efterfølgende semester.

Det konkrete arbejde med at gøre de traditionelle kursuseksamener mere valide og læringsunderstøttende er gået i retning af at øge fokus på: 1) Samarbejde, peer-læring og feedback; 2) Selvansvar og refleksion; 3) Problemorientering og vidensbrug; og 4) Autenticitet. Alle fire fokusområder er væsentlige faktorer i forhold til at fremme dybdelæringsstrategier (Ramsden, 1999; Boud, 1999; Biggs, 2007).

Én eksamensform kan dog dårligt omfatte og udprøve alle opstillede læringsmål for et givent kursus. Og en indsats i udviklingsprojektet i forhold til at få skabt mere synlig alignment har også været at forsøge at opstille mindre omfattende læringsmål for givne kurser og i stedet bruge flere formative evalueringsformer undervejs i kurserne, evt. som indstillingsbetingelse for at aflægge eksamen i kurset eller ved krav om undervisningsdeltagelse (se eksempler senere i artiklen).

\section{Feedback, samarbejde og peer-læring}

Feedback til de studerende på deres studieprodukter har afgørende indflydelse på deres læring (Dysthe, 2011, s. 135). Desuden er det at kunne vurdere andres (fagfællers) faglige præstationer en væsentlig arbejdsmarkedskompetence.

Men det kræver brug af undervisningstid at opkvalificere de studerendes feedbackkompetence. Feedback-kompetence indebærer kompetence $\mathrm{i}$ at kunne opstille og begrunde feedback-kriterier, give og modtage feedback og endelig også at bruge den feedback man får. De studerende har svært ved at bruge den feedback de får, blandt andet fordi der i uddannelserne ikke afsættes tid til revisioner og forbedringer af skriftlige opgaver (Dysthe, 2011, s. 138).

Derfor har det været en vigtig del af udviklingsarbejdet på RUC hvordan man kan lade de studerendes feedback-kompetencer indgå som en del af undervisningen, men også af eksamenen fordi studerende, som tidligere nævnt, prioriterer de ting i undervisningen som de bliver bedømt på til eksamen. Her et par forslag til hvordan feedback-kompetencer kan indgå i eksamen som en del af egen og medstuderendes mundtlige og skriftlige præstationer: 
- Vedlæg en skriftlig feedback givet til en anden (gruppe) studerende(-s) skriftlige produkt ud fra eksplicitte og begrundede feedback-kriterier.

- Aflever en skriftlig feedback givet til en anden (gruppe) studerende(-s) mundtlige præstation ud fra eksplicitte og begrundede feedback-kriterier.

- Vedlæg eksempler på, refleksioner over og begrundelser for egen brug af peer-feedback.

At kunne indgå i samarbejde med medstuderende (fagfæller) er både en væsentlig slutkompetence (Jf. Ny dansk kvalifikationsramme, 2007), og en væsentlig arbejdsmarkedskompetence. Men interaktion, dialog og samarbejde med medstuderende er også væsentligt i forhold til læring ud fra det synspunkt at viden og læring grundlæggende er socialt (Dysthe, 2005).

I de tilfælde hvor samarbejdskompetence hos de studerende har været ét af læringsmålene i et givent kursus, er det oplagt at vælge gruppeeksamen med en eller anden form for fælles produkt (opgave, projekt, formidlingsopgave e.l.). Eller at lade de studerende samarbejde og forberede sig i grupper forud for en eksamen. Men udfordringen i udviklingsprojektet har været at finde nogle måder at dokumentere opnåelsen af samarbejdskompetence på. Her følger nogle af de ideer til dokumentation af samarbejdskompetence fra udviklingsprojektet:

- Vedlæg de væsentligste pointer fra en gruppediskussion som har bidraget til produktets udvikling.

- Vedlæg en redegørelse for hvordan gruppemedlemmernes forskellige faglighed har bidraget til produktet.

- Vedlæg en oversigt over køreregler for gruppearbejdet (deadlines, feedback etc.).

- Vedlæg en redegørelse for hvilke faglige positioner som gruppemedlemmerne har repræsenteret, og hvordan det har indvirket på gruppearbejdet.

- Vedlæg skriftligt materiale med refleksion over gruppens samarbejde (fx arbejdsfordeling, arbejdsmåder, tidsplanlægning, procesdiskussioner, faglige diskussioner, gruppedynamik).

Lige som i tilfældet med øget brug af feedback kræver det undervisnings- og vejledningstid brugt på at opkvalificere de studerendes samarbejdskompetence og give dem feedback på samme. Samarbejdskompetence indebærer blandt andet kompetence i at indgå i faglige diskussioner (argumentere fagligt) og kompetence i samarbejdende skrivning. Det handler ligeledes om at kunne tage ansvar for undersøgeprocesser, udvise fleksibilitet, håndtere forskellige faglige udgangspunkter og forudsætninger. Underviser-feedback og evt. også peer-feedback på ens samarbejdskompetence kræver tid afsat til individuel vejledning fordi samarbejdskompetence også knytter sig til nogle mere personligt funderede træk. 
Her et eksempel fra udviklingsprojektet på hvordan en af uddannelserne på RUC har ændret og udviklet en konkret eksamensform så den i højere grad understøtter peer-feedback, samarbejde og peer-læring. På psykologi på RUC havde man gennem flere år anvendt en eksamensform på ét af fagkurserne som bestod af en 72 timers skriftlig hjemmeopgave på 3-5 sider ud fra bundne spørgsmål kombineret med de studerendes aktive undervisningsdeltagelse. I forbindelse med udarbejdelsen af nye læringsmål for det pågældende fagkursus syntes faget ikke længere at den brugte eksamensform matchede det de på faget gerne ville med kurset. Det medførte følgende ændringer af eksamensformen, her opstillet skematisk med læringsmålene for kurset i venstre kolonne, den hidtil brugte eksamensform i midterste kolonne og endelige den nye eksamensform i højre kolonne.

\begin{tabular}{|c|c|c|}
\hline Læringsmål (uddrag) & $\begin{array}{l}\text { Gammel } \\
\text { eksamensform }\end{array}$ & Ny eksamensform \\
\hline 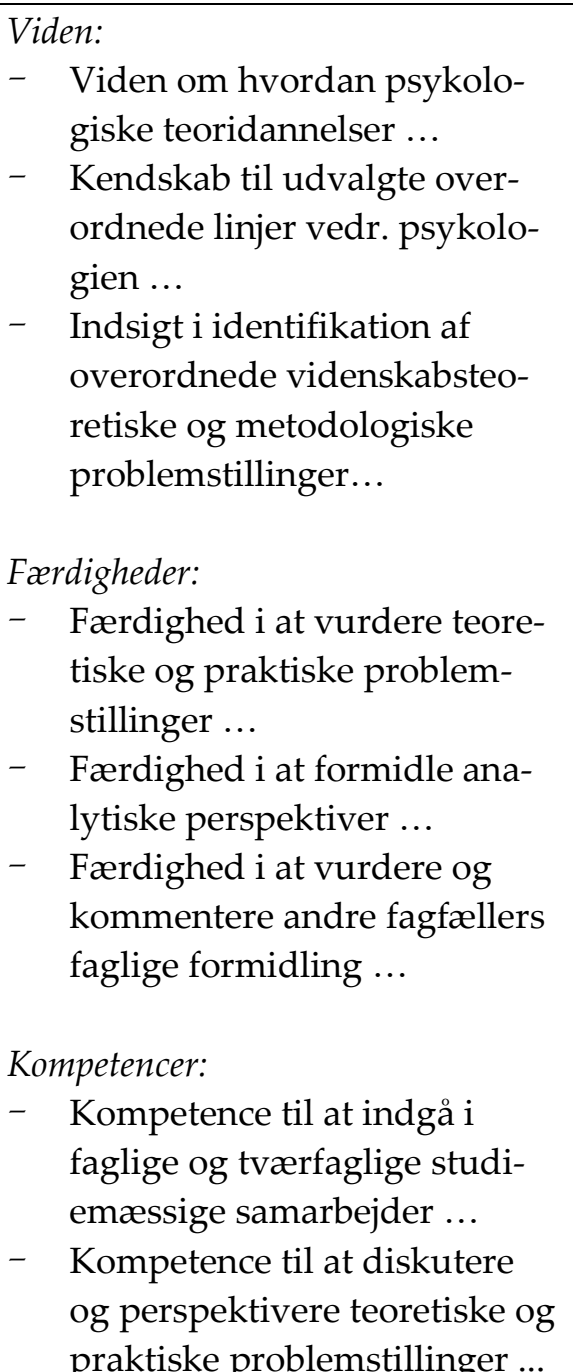 & $\begin{array}{l}\text { En individuel } 72 \\
\text { timers skriftlig } \\
\text { hjemmeopgave på 3- } \\
5 \text { sider ud fra bund- } \\
\text { ne spørgsmål. } \\
\text { Derudover er der } \\
\text { krav om aktiv delta- } \\
\text { gelse i kurset. } \\
\text { Bedømmelse: Bestå- } \\
\text { et/ikke-bestået. }\end{array}$ & $\begin{array}{l}\text { For at bestå fagmodulkurset } \\
\text { skal den studerende aktivt, } \\
\text { regelmæssigt og tilfredsstil- } \\
\text { lende deltage i undervis- } \\
\text { ningen. Det indebærer: } \\
\text { - } \quad \text { Gruppevis udarbejdelse } \\
\text { af en poster og tilhø- } \\
\text { rende handouts. } \\
\text { - } \quad \text { Deltagelse i en poster- } \\
\text { session. } \\
\text { - Udarbejdelse af en } \\
\text { skriftlig feedback til en } \\
\text { opponentgruppes po- } \\
\text { ster. } \\
\text { Bedømmelse: Bestået/ikke- } \\
\text { bestået. }\end{array}$ \\
\hline
\end{tabular}

Tabel 1. Eksempel på sammenhæng mellem læringsmål og eksamensform.

Udover at sætte fokus på samarbejde og peer-feedback har den valgte eksamensform også en stor grad af autenticitet over sig i indhold og i afvikling. 


\section{Selvansvar og refleksion}

Udviklingen af eksamensformer er også gået i retning af at gøre de studerende mere ansvarlige og aktive i valg af eksamensindhold, i udformningen af bedømmelseskriterier og i selve bedømmelsen - egenbedømmelse og peer-bedømmelse. Der ligger stor faglig læring gemt $i$ at skulle udforme eksamensspørgsmål, bedømmelseskriterier og foretage faglige bedømmelser. Det kræver at man kan identificere fagenes kerneindhold, centrale begreber, forståelser, udtryk og arbejdsmåder mv.

I det omfang man kan indtænke nogle af disse elementer i sin tilrettelæggelse af eksamen på en måde så det ikke går ud over de studerendes retssikkerhed eller objektiviteten i eksamen, medvirker det til at gøre eksamen til ikke bare bedømmelse af læring, men også bedømmelse for læring. Her følger nogle ideer til hvordan man kan give de studerende mere ansvar i forbindelse med tilrettelæggelsen af eksamen:

- $\operatorname{De}(n)$ studerende udleder bedømmelseskriterier på baggrund af læringsmål og/eller modelopgaver og vedlægger dem i forbindelse med en opgaveaflevering. Bedømmelseskriterierne indgår i bedømmelsen.

- De(n) studerende bedømmer sig selv kriteriebaseret og vedlægger bedømmelsen i forbindelse med opgaveaflevering. Underviser bedømmer opgaven inkl. egenbedømmelsen - som altså indgår i den samlede bedømmelse.

- Den studerende udformer xx antal eksamensspørgsmål. Underviser vælger hvilket eksamensspørgsmål som den studerende skal besvare (mundtligt eller skriftligt). De øvrige eksamensspørgsmål indgår i bedømmelsen.

- Aktiv undervisningsdeltagelse med kvalitative krav til deltagelse fulgt op af formativ (peer-) feedback ( $f x$ ansvar for undervisningsgang, skrive sammendrag af væsentlige pointer i undervisningen eller i udvalgte pensumtekster, deltage i feedback-seancer, deltage i midtvejsevaluering og slutevaluering, eksaminere underviser i et emne inden for pensum, praktiske øvelser).

Kompetence til at tilrettelægge, evaluere og regulere egne læreprocesser og faglige udvikling er en kompleks kompetence som det er vanskeligt at dokumentere. I kurser som har læringskompetence som et læringsmål, er følgende velkendte og allerede velafprøvede formater og refleksionsgenrer blevet taget $\mathrm{i}$ brug:

- portfolie,

- læringslog,

- studieforløbsbeskrivelser.

Refleksionsteksterne er i udviklingsprojektet blevet vedlagt eller afleveret sammen med traditionelle skriftlige opgaver og projekter indeholdende refleksioner over $\mathrm{fx}$ :

- egne læringsmål i relation til et givent kursus læringsmål,

- progression i egen faglige udvikling, 
- progression i tilrettelæggelsen af eget studieforløb/uddannelse,

- læringsmål fremadrettet i studiet - og læringsbehov,

- brug af medstuderende (feedback og faglig sparring),

- arbejdsmåder og læringsstile.

\section{Problemorientering og vidensbrug}

Problemorientering understøtter ligeledes de studerendes dybdestrategier. De studerende skal i problemorienterede opgaver transformere viden gennem analyser og diskussioner, i mødet mellem teori og empiri, og de skal strukturere sammenhængende, argumenterede svar eller bud på svar på en problemstilling. Ud over den problemorienterede projektarbejdsform, der som bekendt er en meget central arbejdsform på RUC, har vi i udviklingsprojektet også drøftet mulighederne for i forbindelse med kursuseksamenerne at udforme eksamensspørgsmål som er mere problemorienterede og efterspørger refleksion og handleanvisning.

\section{Autenticitet}

I Kvalifikationsrammen betones det som tidligere nævnt, at de studerende når de er færdige med deres uddannelse, ikke bare er i besiddelse af et bestemt vidensindhold/-niveau, men også kan anvende og beherske generelle færdigheder der knytter sig til beskæftigelse inden for det pågældende fagområde. Et fokus på hvordan teoretisk viden kan anvendes i mere autentiske situationer i undervisnings- og eksamenssammenhænge fremmer de studerendes dybdestrategier fordi stoffet har betydning og relevans for de studerende og fordrer at de relaterer, perspektiverer, reflekterer og ser sammenhænge i det stof og de problemstillinger de arbejder med.

I den sammenhæng er blandt andre nedenstående eksamensformer relevante hvor bedømmelseskriterierne går på de studerendes kompetencer til at kunne forbinde teori og praksis:

- portfolieeksamener,

- case-baserede opgaver,

- praktikbaserede opgaver,

- aftagerstillede opgaver,

- autentiske genrer: konsulentrapport, briefing, ministertale, sagsnotat, projektdesign, foredrag, presentation, poster - evt. med medstuderende som tilhører,

- kombinationer af skriftlige og mundtlige eksamensformer.

\section{Den fortsatte pædagogiske udvikling}

Der er flere måder at facilitere universitetspædagogisk udvikling: Kurser, lærerseminarer, team teaching, sparring, supervision, aflønning/tillæg, udviklingstimer etc. I dette udviklingsprojekt har jeg som universitetspædagogisk konsulent sparret med studieledere og undervisere lokalt på fagene i takt med deres aktuelle behov. I for- 
bindelse med udformningen af nye studieordninger har der været stor interesse hos fagene for at drøfte alignment, læringsmål, bedømmelsekriterier og eksamensformer. Det har medvirket til en frugtbar og konstruktiv proces kombineret med at RUC i det hele taget prioriterer og understøtter pædagogisk udvikling som en vigtig del af universitetets samlede kvalitetsudviklingssystem.

En af udfordringerne i projektet har været det forhold at ændringer af uddannelsernes slutprodukter, nemlig eksamenerne, har konsekvenser bagudrettet for undervisningens mål, indhold og tilrettelæggelse, og kræver dermed grundlæggende fagdidaktiske diskussioner på fagene forud. Det kræver genovervejelser over undervisningens "hvad", "hvorfor" og "hvordan" når uddannelserne skal understøtte udviklingen af ikke alene kognitive kompetencer, men også sociale, affektive og metakognitive kompetencer. Og når uddannelserne i forlængelse heraf skal lægge øget vægt på praktisk anvendelse af viden. Derfor sker udvikling og ændring af eksamensformer heller ikke "over night", men er en proces der involverer ændring af undervisningen og af hele læringsforløbet.

Signe Skov er cand.mag. i Dansk og Pædagogik og specialkonsulent på RUC hvor hun blandt andet arbejder med udvikling af eksamensformer, bedømmelseskriterier og læringsmål samt disses sammenhæng med undervisnings- og vejledningsformer. Tidligere var Signe skrivekonsulent på Det Humanistiske Fakultet på Københavns Universitet hvor hun har undervist og vejledt i opgaveskrivning, specialeskrivning, projektstyring og skriveprocesser. For da var hun dansklærer på det daværende Blaagaard Lærerseminarium (nu Professionshøjskolen UCC) hvor hun var med til at starte et skrivecenter. Signe er blandt andet medforfatter til Specielt om specialer - en brugsbog (2011), og bidragsyder til Den gode opgave (2012). Hun har desuden skrevet bogen Bundne opgaver - hjemmeopgaver og eksamensopgaver på videregående uddannelser (2008) og står bag udviklingen af Specialebloggen (http://specialebloggen.blogs.ku.dk/) og to internaktive test $i$ godt akademisk sprog (http://hum.ku.dk/uddannelser/vejledning/sprogtest/).

\section{Referencer}

Andersen, H. L. \& Tofteskov, J. (2008). Eksamen og eksamensformer-betydning og bedømmelse. Frederiksberg: Samfundslitteratur.

Assessment Standards Knowledge exchange (2007/2009). http://www.brookes.ac.uk/aske/ (tilgået 09.02.12).

Bedømmelse og censur (2006). Dansk Universitetspædagogisk Tidsskrift, 1.

Biggs, J. \& Tang, C. (2007). Teaching for Quality Leaning at University. (3. oplag). England: Open University Press.

Boud, D. \& Associates (2010). Assessment 2020: Seven propositions for assessment reform in higher education. Sydney: Australian Learning and Teaching Council.

http://www.iml.uts.edu.au/assessment-futures/Assessment2020 propositions final.pdf (tilgået 14.02.13).

Boud, D., Cohen, R. \& Sampson, J. (1999). Peer learning and assessment. I: Assessment and Evaluation in Higher Education, 24, s. 413-426. 
Boud, D. \& Falchikov, N. (2006). Aligning assessment with long-term learning. I: Assessment and Evaluation in Higher Education, 31, s. 399-413.

Dysthe, O. (2011). What is the Purpose of Feedback when Revision is not Expected? A Case Study Design in a First Year Master's Programme. I: Journal of Academic Writing, 1, s. 135-142.

Dysthe, O. \& Engelsen, K. S. (red.) (2005). Mapper som pædagogisk redskab. Perspektiver og erfaringer. Århus: Forlaget Klim.

Gibbs, G. \& Simpson, C. (2004): Does your assessment support your student's learning? I: Journal of Teaching and Learning in Higher Education, 1, s. 1-30.

Krogh, L. (2011). Validiteten af eksamener på videregående uddannelser. I: Andreasen, K., Friche, N., Rasmussen, A. (red.): Målt E Vejet. Uddannelsesforskning om evaluering. Aalborg: Aalborg Universitetsforlag, s. 109-135.

Lauvås, P. \& Jacobsen, A. (2004). Exit Examen - eller?: former for summativ evaluering $i$ høgre utdanning. Oslo: Cappelens Forlag.

Ministeriet for Forskning, Innovation og Videregående Uddannelser (2012). Eksamensbekendtgørelsen af 24. juni 2012.

Ministeriet for Forskning, Innovation og Videregående Uddannelser (2008). Dansk kvalifikationsramme for de videregående uddannelser. (tilgået 20.02.13).

Ramsden, P. (1999). Strategier for bedre undervisning. København: Gyldendal.

Sadler, R. (1998). Formative assessment: Revisiting the territory. I: Assessment in Education, 5, s. 77-84. 